NBER WORKING PAPER SERIES

REPAIRING A MORTGAGE CRISIS:

HOLC LENDING AND ITS IMPACT ON LOCAL HOUSING MARKETS

Charles Courtemanche

Kenneth A. Snowden

Working Paper 16245

http://www.nber.org/papers/w16245

\author{
NATIONAL BUREAU OF ECONOMIC RESEARCH \\ 1050 Massachusetts Avenue \\ Cambridge, MA 02138 \\ July 2010
}

Snowden is corresponding author. We thank Price Fishback, Stephen Holland, and seminar participants at the University of North Carolina Greensboro, the St. Louis Federal Reserve and the 2010 ASSA Meetings for comments and suggestions. We also thank David Cornejo, Diana Liu, Anders Olson, and Spencer Snowden for assistance in assembling the data. All errors are our own. The views expressed herein are those of the authors and do not necessarily reflect the views of the National Bureau of Economic Research.

NBER working papers are circulated for discussion and comment purposes. They have not been peerreviewed or been subject to the review by the NBER Board of Directors that accompanies official NBER publications.

(C) 2010 by Charles Courtemanche and Kenneth A. Snowden. All rights reserved. Short sections of text, not to exceed two paragraphs, may be quoted without explicit permission provided that full credit, including (๑) notice, is given to the source. 
Repairing a Mortgage Crisis: HOLC Lending and its Impact on Local Housing Markets Charles Courtemanche and Kenneth A. Snowden

NBER Working Paper No. 16245

July 2010

JEL No. E44,G01,G18,G21,G22,G28,N22,N62,N92,R31,R51

\begin{abstract}
$\underline{\text { ABSTRACT }}$
The Home Owners' Loan Corporation purchased more than a million delinquent mortgages from private lenders between 1933 and 1936 and refinanced the loans for the borrowers. Its primary goal was to break the cycle of foreclosure, forced property sales and decreases in home values that was affecting local housing markets throughout the nation. We find that HOLC loans were targeted at local (county-level) housing markets that had experienced severe distress and that the intervention increased 1940 median home values and homeownership rates, but not new home building.
\end{abstract}

Charles Courtemanche

Bryan School of Business and Economics

P.O. Box 26165

University of North Carolina at Greensboro

Greensboro, NC 27402

cjcourte@uncg.edu

Kenneth A. Snowden

Bryan School of Business and Economics

P.O. Box 26165

University of North Carolina at Greensboro

Greensboro, NC 27402

and NBER

snowden@uncg.edu 


\title{
REPAIRING A MORTGAGE CRISIS: \\ HOLC LENDING AND ITS IMPACT ON LOCAL HOUSING MARKETS
}

\begin{abstract}
The Home Owners' Loan Corporation purchased more than a million delinquent mortgages from private lenders between 1933 and 1936 and refinanced the loans for the borrowers. Its primary goal was to break the cycle of foreclosure, forced property sales and decreases in home values that was affecting local housing markets throughout the nation. We find that HOLC loans were targeted at local (county-level) housing markets that had experienced severe distress and that the intervention increased 1940 median home values and homeownership rates, but not new home building.
\end{abstract}

\begin{abstract}
“[A] tremendous surge of residential building in the [last] decade... was matched by an everincreasing supply of homes sold on easy terms [and only]... a small decline in prices was necessary to wipe out this equity. Unfortunately, deflationary processes are never satisfied with small declines in values. They feed upon themselves and produce results out of all proportion to their causes... In the field of real-estate finance, particularly, we have depended so much upon credit that our whole value structure can be thrown out of balance by relatively slight shocks. When such a delicate structure is once disorganized, it is a tremendous task to get it into a position where it can again function normally." (Hoagland, 1935)
\end{abstract}

\section{Introduction}

Between 1929 and 1933 hundreds of thousands of homeowners defaulted on mortgages, thousands of mortgage lending institutions failed, and surviving mortgage lenders dramatically curtailed their lending operations. Observers of events since 2007 will find striking parallels in the background and character of the housing and mortgage crisis of the 1930s. That episode also followed a decade of rapid growth and innovation in the residential mortgage market that quickly reversed into a self-reinforcing cycle of loan delinquency, foreclosure, forced property sales and decreases in home values. ${ }^{1}$ Henry Hoagland was well-positioned to characterize the crisis as a member of the Federal Home Loan Bank

\footnotetext{
${ }^{1}$ See Wheelock (2008) for an overview of the housing boom of the 1920s and crisis in the 1930s.
} 
Board. The FHLBB supervised most depression-era housing programs including the Home Owners' Loan Corporation which was in the midst of refinancing about one million delinquent mortgages when Hoagland penned his observations in 1935. All of these distressed loans were held by private mortgage lenders before HOLC purchased and refinanced them, so the program provided assistance not only to homeowners but also to a severely disrupted mortgage market. By 1936 HOLC held mortgage loans on 1 out of every 10 nonfarm owner-occupied home in the U.S. and held nearly 20 percent of the nation's home mortgage debt.

Because it combined the purchase of distressed mortgages with a loan modification program, the HOLC could have ameliorated the impacts of the 1930s crisis through three different channels. ${ }^{2}$ First, by refinancing so many distressed loans it immediately reduced the number of home foreclosures and moderated the cycle of forced home sales, lower housing prices and additional foreclosures. Second, HOLC continued to reduce the number of foreclosures after its lending operations ended in 1936 by adopting generous servicing and work-out policies (Harriss, 1951, 64-70). ${ }^{3}$ Finally, HOLC strengthened the balance sheet of private home lending agencies by substituting liquid, low-risk, government-insured bonds for delinquent mortgages so that they could be more patient servicers of their remaining loans and resume new mortgage lending activities. ${ }^{4}$

\footnotetext{
${ }^{2} \mathrm{HOLC}$ is an interesting case study for observers of the recent mortgage crisis because it combined purchases of toxic mortgages with loan modifications. During the recent crisis, in contrast, programs have been designed to perform only one of these functions. Toxic mortgage loans, for example, were supposed to have been purchased by the Troubled Assert Relief Program (TARP) and the Public-Private Investment Program (PPIP). Loan modification programs, on the other hand, have included the White House/Treasury HAMP and HARP programs, the FDIC's IndyMac Loan Modification program and Federal Housing Finance Agency‘s program to modify loans held by FannieMae or FreddieMac.

${ }^{3}$ Harriss (1951, 64-71) describes HOLC's loan servicing model which included postponement of principal payments for the first three years and extensive personal contact and counseling if the loan became delinquent. HOLC, nonetheless, foreclosed on 20 percent of its loans.

${ }^{4}$ HOLC paid for mortgages with its own bonds on which both principal and interest were guaranteed by early 1934 and for which a broad secondary market developed. HOLC bonds paid low interest rates ( 3 or 4 percent) relative to mortgages, but they were replacing delinquent mortgages in investors' portfolios.
} 
Table 1 provides a broad overview of the disruptions in the residential mortgage market during the 1930s and the magnitude and scope of HOLC activities against that backdrop. Between 1930 and 1933 privately-held mortgage debt on 1-4 family nonfarm homes contracted by \$3.6 billion or about 19 percent of the total. The bulk of the decrease occurred in the portfolios of Building \& Loans and individual investors which were the two investor groups most heavily connected to innovation and growth within the residential of mortgage market during the 1920s. ${ }^{5}$ Over the next three years privately held mortgage debt fell by another 17 percent and, as be seen in the third and fourth rows of Table 1 , HOLC purchases represented nearly two-thirds of the decrease for Building \& Loans and more than the total decrease for individual investors, mutual savings banks and commercial banks. The payments lenders received from these transactions, moreover, were sufficient to fund more than 80 percent of the subsequent increase in mortgage holdings between 1936 and 1940 for each lending group except insurance companies.

\section{[INSERT TABLE 1 ABOUT HERE.]}

HOLC loan purchases were substantial in magnitude and widely distributed, but privately held home mortgage debt still decreased by 20 percent between 1930 and 1940 while nonfarm homeownership fell from 46 percent to 41 percent and the median value of nonfarm homes decreased by 37 percent. But even though HOLC did not reverse all of the damage from the crisis, its lending and purchase programs might have mitigated the impacts if they were well-targeted and effective. We explore that possibility in this paper. After briefly discussing the literature on the HOLC, we examine county-level rates of HOLC applications, approvals and loans and find that they were all related to indicators of economic and housing distress as well as other demographic, economic and political characteristics. Among these other

\footnotetext{
${ }^{5}$ Difficulties that persisted throughout the decade includes the foreclosed real estate accounts of Massachusetts mutual savings banks which still represented two-thirds of their capital surplus in 1940, the liquidation of 1920s securitization structures that occupied state and federal regulators into the early 1940s and the Building \& Loan which lost 3,000 associations after 1933 and still held 12 percent of its assets in real estate in 1940. See Lintner $(1948,272)$ for the mutual savings banks, Snowden (2003) for the B\&L industry and Snowden (2010) for the failure of the mortgage guarantee companies and real estate bond houses during the 1930s.
} 
influences was the distance between the county and the nearest HOLC office which indicates, unsurprisingly, that residential mortgage markets were still spatially segmented by information and transaction costs in the 1930s. ${ }^{6}$ Based on this evidence, we exploit the spatial configuration of the HOLC program to identify the impacts of HOLC lending on home values and homeownership rates in 1940, and on new housing construction in 1935-1940. We find that HOLC lending boosted home values and homeownership rates during the second half of the 1930s, but that the program did not stimulate new home construction.

\section{Background and Literature on HOLC}

HOLC was a remarkable federal initiative in at least two respects. First, the agency organized and began to operate a truly national mortgage loan origination network just a few months after being created in the summer of 1933. Second, the corporation dissolved as originally intended in 1951 after it had finished servicing the loan portfolio that it had created between 1933 and 1936. Harriss (1951) describes HOLC procedures, operations and structure over this entire life span and his account remains the indispensable reference for any analysis of the agency. ${ }^{7}$ To gain insights about the program's operation and effectiveness, however, Harriss's largely descriptive account needs to be supplemented with systematic examination of three issues: the factors which determined participation by homeowners and lenders in the HOLC program, the forces which shaped the allocation of HOLC loan purchases and refinancing across the nation's markets, and the program's impact on local and national housing market outcomes. In this paper we make contributions along all three fronts. ${ }^{8}$

By name and legislative intent HOLC was first and foremost a program designed to assist distressed homeowners, but no one has yet systematically examined why nearly two million households

\footnotetext{
${ }^{6}$ Snowden $(1997,2003)$ documents spatial segmentation in the residential mortgage market before 1930.

${ }^{7}$ Tough (1951) also provides an important view of the ultimate success of HOLC at the program's end.

${ }^{8}$ The research employs newly digitized county-level data on number of HOLC applications and acceptances (from U.S. Federal Home Loan Bank Board 1937 Annual Report) and the number of homes built in four quinquennia: 1920-24, 1925-29, 1930-35 and 1935-40 (from 1940 U.S. Census of Housing).
} 
applied to HOLC for mortgage relief between 1933 and $1936 .{ }^{9}$ We do so and find that variation in HOLC application rates across counties reflected, most importantly, the structure of local housing markets and the distress felt within them. We take this as evidence that the program successfully attracted applicants who were in need of loan modification rather than individuals seeking general economic relief.

We also examine the determinants of the rate at which these applications were accepted into the program. Rose (2009) has examined the issue for a sample of individual HOLC loans made in New York, New Jersey and Connecticut with a focus on the terms that the agency offered to lenders in its role as a "bad bank". ${ }^{10}$ He shows that the agency set appraisals, loan balances and loan prices above the levels warranted by current property values in order to encourage the participation of lenders by reducing the losses on loan sales that they had to write down. ${ }^{11}$ Rose's work establishes that HOLC acceptance rates were determined by the interaction of several factors - the program's eligibility requirements, staff judgments regarding borrower need and property value, and the negotiating strength of lenders. We assess the net impact of all of these by examining the determinants of county-level acceptance rates into the program. We find that the pattern of acceptance at this level of aggregation was closely associated with local housing characteristics and measures of distress that should have mattered in a targeted mortgage relief program.

Our measure of HOLC loan activity — the percentage of 1930 nonfarm households in each county that received HOLC refinancing - is the product of the loan application and acceptance rates and so was determined by similar influences. In the second section we estimate the impact that HOLC intervention had on three outcomes in local housing markets-home values and homeownership rates in 1940 and the

\footnotetext{
${ }^{9}$ Harriss (1951, 16-23) provides a descriptive account for HOLC applicants in the aggregate.

${ }^{10}$ See Ergungor (2007) and Bernanke (2009) for discussions of modern versions of "bad banks" to purchase toxic assets in Sweden, Peru and other countries during crises.

${ }^{11}$ Under HOLC procedures the higher appraisals also increased the amounts borrowers had to refinance on their HOLC loans. Rose's work clarifies, therefore, that HOLC faced a tradeoff by serving both sides of the mortgage transaction - actions and policies that generated greater lender participation also raised the delinquency rate on HOLC's own loan portfolio.
} 
number of new homes built in each county between 1935 and 1940 . We chose these measures to assess the program's impact on goals that were emphasized in legislation and contemporary discussionpreserving homeownership, stabilizing home values and stimulating a recovery in residential construction activity. The distinction among the three is important because other major New Deal housing programs, most notably the FHA mortgage insurance program, were specifically designed to stimulate home building. Taken in this light our findings reveal an interesting and revealing pattern-HOLC loan activity increased home values and homeownership rates in 1940, but not residential construction.

In concurrent work Fishback, Lagunes, Horrace, Kantor, and Treber (2010) (henceforth FLHKT) also examine the impact of HOLC lending and find that it had positive effects on home values and the stocks of owned and rented homes in the 2,463 counties with 1930 populations below 50,000. We also find HOLC impacts on home values and ownership for a restricted sample of counties, but in our case this includes counties (more than 2,730) that did not contain an HOLC loan office. In the next-to-last section we examine the differences in the methods we and FLHKT used and, more importantly, differences in the interpretations of the results. FLHKT conjecture that HOLC intervention was more effective in smaller, less populated counties because the institutional structure of mortgage markets was thinner in these areas than in larger cities. We argue, in contrast, that the "distance-from-HOLC office" instrument that is used in both papers to identify treatment effects is an effective instrument only outside the relatively large counties in which HOLC offices were located. Our view, therefore, is that the impact of HOLC within the nation's largest urban markets remains an important, but open, issue.

The story of HOLC complements other literature that has shown that disruptions in credit markets contributed to both the depth and length of the Great Depression. Mishkin (1979) attributes the dramatic fall in consumption spending in the early 1930s to the negative impacts that decreases in stock values and home prices, and increases in the real burden of debt, had on household balance sheets. HOLC was designed to ameliorate the housing market shocks that Mishkin examined, but also the disruptions associated with foreclosure that his analysis did not address. Bernanke (1983), on the other hand, establishes context for the second side of the HOLC story - the impact the agency had on mortgage 
lending institutions. Bernanke showed that an index of bank failure, which he uses to proxy for the "cost of credit intermediation," helps to explain the severity of the decline in real output during the 1930s. No segment of the nation's financial structure suffered greater damage during the 1930s than the mortgage market. Taken in this light, Bernanke's argument provides good reason to view HOLC as an attempt to repair credit channels. We conclude that it did.

\section{Allocation of HOLC Loans across Counties}

In its Fifth Annual Report in 1937, the Federal Home Loan Bank Board reported the number of HOLC loans applied for and the number made for each county between 1933 and 1936. Scaling these numbers by the number of occupied and owner-occupied nonfarm housing units as measured in the Census of 1930, we construct four measures of HOLC loan activity: 1) the number of HOLC applications in each county as a percentage of owner-occupied nonfarm homes in 1930 (application rate), 2) the percentage of HOLC applications accepted for purchase and refinancing (acceptance rate), 3) the number of homes refinanced by HOLC as a percentage of the number of owner-occupied homes in 1930 (loan rate 1), and 4) the number refinanced as a percentage of all nonfarm homes in 1930 (loan rate 2). The first panel of Table 2 shows that fourteen percent of owner-occupied households in the average county applied for HOLC loans, that an average of just under fifty percent of applications were accepted, and that HOLC financed an average of just over 7 percent of owned homes, or 3.6 percent of all nonfarm homes. ${ }^{12}$

\section{[INSERT TABLE 2 ABOUT HERE.]}

We examine county-level variation in application, acceptance and loan rates in this section to gain insight into the characteristics of borrowers who applied for HOLC relief, the factors that were associated with HOLC loan approval and the considerations that explained the pattern of HOLC activity across local housing markets. The overall HOLC loan rate for each county is simply the product of the application and acceptance rates, so we focus on the latter two first.

\footnotetext{
${ }^{12}$ Harriss $(1951,21)$ approximates application rates as percentages of estimates of owner-occupied, mortgaged homes in each state, but he admits the estimates are crude because they rely on patterns of mortgage drawn from the 1940 Census of Housing.
} 
HOLC mortgages dominated refinancing alternatives available from private lenders in 1933 because the agency's loans were offered on relatively generous terms and were readily available for eligible borrowers. The HOLC loan rate, for example, was 5 percent when prevailing rates in the private market were six percent and higher. ${ }^{13}$ The agency could also lend up to 80 percent of generously appraised home values for a term of fifteen year terms with full amortization of principal. HOLC helped popularize the familiar modern mortgage contract, in fact, at a time when the contractual structure of the mortgages that had financed the housing boom of the 1920s contributed to severe disruptions and rationing in the private mortgage market. Many homeowners, for example, were forced to find new lenders in the early 1930s who would refinance short-term, straight mortgage loans on which only interest had been paid up to that point; many other borrowers lost equity they had accumulated in Building \& Loan shares that served as a sinking fund to pay off the loans they had taken out from these institutions. ${ }^{14}$ So by 1933 hundreds of thousands of mortgagors sought refinancing or renegotiation on existing mortgage loans at the same time thousands of private lending institutions had failed and surviving mortgage lenders were severely curtailing their lending operations.

In this environment Harriss $(1951,22)$ estimates that 40 percent of the nation's home mortgage borrowers applied for HOLC loans; given the generous terms offered by the agency it is perhaps surprising that even greater numbers did not apply. The demand for HOLC loans was restricted, however, by eligibility requirements that should have controlled whether a loan application was approved and, therefore, the number and types of borrowers who would have found it worthwhile to apply. ${ }^{15}$ The program was designed to serve only nonfarm owners of 1-to-4 family residential property who had

\footnotetext{
${ }^{13}$ Volume II of the reports from the 1932 President's Report on Homeownership provides an extensive discussion of loan terms available in the private mortgage market. See Gries and Ford, 1932, 52-97.

${ }^{14}$ Snowden (2003) describes the fragility of the traditional share accumulation loan used by B\&Ls during the 1930s mortgage crisis.

${ }^{15}$ See Rose (2009) for an examination of the HOLC acceptance decision at the individual loan level for a sample of loans that the agency made in New York, New Jersey and Connecticut. He focuses on how HOLC used the appraisal decision to elicit lender's willingness to sell their loans.
} 
become delinquent on an existing mortgage. HOLC loans were also restricted in size: to no more than 80 percent of the property's appraised value, to amounts of not more than $\$ 14,000$, and to property that was valued at no more than $\$ 20,000$. In addition, the applicant had to establish that she had been unable to refinance with a private lender, that she was financially capable of fulfilling the terms of the HOLC loan and that her property was sufficiently valuable to leave the agency whole if she did not.

HOLC was not designed to be a general relief program, therefore, but to serve as a temporary, targeted intervention to fill gaps in a severely disrupted private mortgage market. To determine whether this mission actually shaped the character of loan applications and the patterns of loan approval, we employ a modified version of the empirical model that Fishback, Kantor and Wallis (2003) (henceforth FKW) used to examine variations in county-level per capita spending levels for 20 New Deal grant and loan programs, including HOLC. FKW were particularly concerned in assessing whether the variation in spending levels across localities was associated strictly with the need for relief, recovery and reform, or whether political considerations were also at work. To measure these influences they included demographic controls (population, density, urban, race and literacy), measures of economic structure and income (importance and size of farms, and per capita levels of tax returns and retail sales), proxies for distress (unemployment in 1930 and farm failures and the change in retail sales between 1929 and 1933), and a rich set of political variables. ${ }^{16}$

We augment their model with a number of additional independent variables in an effort to build a model specifically tailored to HOLC as opposed to New Deal programs in general. We add to the set of demographic characteristics variables representing age, gender, marital status and nativity, all of which should have influenced the rate and method of financing homeownership. We then add to the set of economic structure variables the share of gainful workers employed in manufacturing, retail and wholesale establishments to provide a fuller picture of the makeup of the nonfarm economy in each

\footnotetext{
${ }^{16}$ We thank FKW for the use of their political variables, retail sales and tax return measures. We omit their committee chair political variables, as we were unable to find a clear connection between them and any of our dependent variables.
} 
county. ${ }^{17}$ Perhaps most importantly, we add to the set of distress variables a county-level measure of housing market distress - the percentage change between 1925-1929 and 1930-1934 in the number of nonfarm dwelling units built. ${ }^{18}$ We consider this a key measure of disruption in local housing and mortgage markets that should have influenced the perceived need for HOLC refinancing among borrowers and the judgments of HOLC administrators about that need.

We also build on FKW's model by including a set of additional housing market variables to capture factors that should have influenced eligibility for HOLC refinancing and, therefore, both application and acceptance rates. First and foremost, the property already had to be encumbered to be considered for an HOLC loan. Some of the demographic variables - such as population, density, and the proportion of the population that was urban and middle-aged — should proxy for access to mortgage finance within the county prior to the crisis. To these we add the natural logarithms of nonfarm median home values in 1930 and the number of new homes built between 1925 and 1929 since newer and higherpriced homes were more likely to have already been encumbered by 1930 . High-priced homes of recent vintage should also have appraised for greater property values in 1933, so these same two variables could have been associated with higher acceptance as well as application rates. We also include the nonfarm homeownership rate in each county to see if loan applications or acceptances were sensitive to the mix of owned and rented housing in the local market. ${ }^{19}$

Finally, we add distance from the nearest HOLC office location to our specification to reflect one of HOLC's most impressive accomplishments - in a matter of months the agency created a loan origination and servicing network that was truly national in scope. HOLC had opened more than 200

\footnotetext{
${ }^{17}$ The demographic and economic structure variables were taken from ICPSR data set 2896.

${ }^{18}$ The 1930 and 1940 median nonfarm home values are taken from ICPSR data set 2896. The number of nonfarm housing units built in each county between 1925-1929, 1930-1934 and 1935-1940 were taken from the self-reported "vintage" data for the housing stock that was reported in Volume II of the 1940 Census of Housing of 1940.

${ }^{19}$ The application rate and loan rate 1 dependent variables already incorporate the county's homeownership rates by construction, so we add the homeownership rate to the model to assess if local tenure patterns had an impact other than arithmetic on application and acceptance rates.
} 
offices by 1934 , with at least one in every state. ${ }^{20}$ Office location mattered for HOLC lending volume because distance increased the costs of mortgage lending for both borrowers and the agency — appraisals required onsite inspections and mortgage applications and documents had to move among homeowners, county officials and HOLC staff. We include an indicator for counties containing an HOLC office, another for counties located within 15 miles of an office but not containing an office, and a third for counties located between 15 and 30 miles away from the nearest office. The omitted base category is a distance of greater than 30 miles. $^{21}$

Our model, therefore, includes seven sets of regressors and takes the following form:

$$
\begin{aligned}
\text { HOLC }_{i s}=\beta_{0}+ & \beta_{1} \text { DEMO }_{i s}+\beta_{2} \text { ECON }_{i s}+\beta_{3} \text { INC }_{i s}+\beta_{4} \text { DISTRESS }_{i s}+\beta_{5} \text { POL }_{i s}+\beta_{6} \text { HOUS }_{i s} \\
& +\beta_{7} \text { OFFICE }_{i s}+\alpha_{s}+\varepsilon_{i s}
\end{aligned}
$$

where $i$ and $s$ index counties and states. HOLC represents either loan rate, application rate, or acceptance

rate. DEMO, ECON, INC, DISTRESS, POL, and HOUS are the sets of demographic, economic structure, income, distress, political, and housing variables. OFFICE includes the variable for whether there was an HOLC office in the county as well as the two distance variables. Following FKW, we include state fixed effects, denoted by $\alpha_{s}$. Table 2 provides descriptive statistics for variables in each of these categories, along with information on whether they were included in FKW's model.

\footnotetext{
${ }^{20}$ The location of HOLC offices in 1934 were taken from Federal Home Loan Bank Board (1934) which provides the location of all HOLC offices on January 15, 1934 by which time 880,000 applications, or more than 40 percent of the 1933-35 total, had been filed. At this time FHLB reported 301 offices, of which 79 were listed as agencies, sub-district offices or wholesale operations offices. For this paper we defined HOLC offices to be only the 48 state offices and 174 district offices open as of January 1934-these combine into 209 counties which contained an HOLC office in our sample. HOLC continued to open offices and by November 1934 there were a total of 458 offices at which HOLC applications could be filed. The number of offices fell beyond this point (Harriss, 140).

${ }^{21}$ We measure distance between the center of each county and the city in which nearest HOLC office was located. We considered alternative distance specifications but found no evidence that additional distance impacted HOLC loan rate beyond 30 miles. Within the 30 mile range, we chose 15 -mile groupings of counties because these distances maximize the F statistic from a test of joint significance of the office variables.
} 
A comparison of the results for the application and acceptance regressions (see columns 1 and 2 of Table 3) reveals interesting patterns about the broad set of factors that were at work in the interactions among borrowers, lenders and the HOLC staff. The bottom rows of Table 3 report F-statistics for the joint significance of the different categories of independent variables. The demographic, economic structure, income and political variables explain more of the variation in application rates than in acceptance rates across local housing markets. The distress, housing and distance variables taken as groups, on the other hand, explain substantial variation in the rate at which applications were both filed and accepted. These latter groups of variables have been chosen to reflect the structure of local housing markets, and the distress and lending costs within them. The importance of these influences as a group provides evidence that HOLC staff, borrowers and lenders all understood the goals and limits on HOLC as a targeted housing program.

The third and fourth columns of Table 3 report the regression results for the number of HOLC loans as a percentage of owner-occupied homes (loan rate 1) and a percentage of all nonfarm homes (loan rate 2). The former is simply the product of the application and acceptance rates in each county so these results provide a useful representation of the impacts of specific variables on application and acceptance rates. The latter is the best measure of the overall extent of HOLC treatment in the county and will therefore be important when examining impacts in the next section. We can partition the factors that influenced variations in overall HOLC loan activity across counties into three groups: those that only had a statistically significant effect on application rates, those that only had a significant effect on acceptance rates and those had significant effects on both. We begin the discussion with the last group.

Marital status and middle-age were associated with both higher application and acceptance rates and therefore loan rates - in our national sample of counties just as Harriss (1951, 51-2) found for a sample of HOLC loans made in New York, New Jersey and Connecticut. His explanation was that middle-aged heads of households applied to HOLC in greater numbers because they were more likely to have outstanding mortgages than younger, older or single persons. They were also more likely to be approved for the loan because they had relatively steady employment and income. Application, 
acceptance, and loan rates were also higher in counties with larger shares of population that were urban, literate and composed of races "other" than black or white.

Two of the key housing variables also impacted both application and acceptance rates - and therefore loan rates - in the expected direction. Most importantly, greater numbers of homeowners applied to HOLC and more of these applications were accepted in counties where housing distress was high. Markets in which median values were higher in 1930 also had higher rates of applications and acceptances, presumably because high pre-crisis values indicated a more extensive reliance on mortgages and stronger post-crisis collateral. Additionally, multiple specification tests (not reported) revealed that the impact of median home value on the dependent variables was concave, suggesting that increases in median home values beyond some point indicated a greater proportion of homes in the county exceeding HOLC dollar restrictions. ${ }^{22}$ Application, acceptance and loan rates also all increased in counties where it was less costly to file and assess an application because of the presence of an HOLC office.

Several factors were associated with statistically significant increases in HOLC application and loan rates but not acceptance rates. These included differences in demographic characteristics (smaller population and higher proportions of males and blacks), economic structure (fewer manufacturing and more retail employees), income (fewer tax returns per capita) and voting patterns (strong party loyalty). Most notably, the positive impact of the volume of new homes built between 1925 and 1929 on countylevel application rates comports with evidence Harriss $(1951,57)$ found in his sample of HOLC loanshomes built and purchased recently were more likely to have been under mortgage and eligible for refinancing. The HOLC acceptance rate, however, was not affected by the age of a county's housing stock.

\footnotetext{
${ }^{22}$ For instance, if we use the level instead of the log for median home values, the squared term is also highly significant. Also, the proportion of homes valued above $\$ 10,000$ dollars in 1930 had a significant negative impact on both application and acceptance rates when median home value was entered linearly, but not when the log of median value was included.
} 
Two variables that reflect policies implemented by HOLC staff had statistically significant effects on acceptance and loan rates but not application rates. Applications were approved at lower rates in counties with high number of farm failures because HOLC staff was instructed to transfer applications from farmers to the Farm Credit Administration (Harriss, 24). Applications were accepted with greater frequency in markets with higher rates of homeownership, consistent with Harriss' observation $(1951,51)$ that HOLC viewed properties located in settled, established residential areas more favorably than those in mixed, transitional neighborhoods.

Three other variables were weakly associated with higher acceptance rates, but had no significant impact on overall HOLC loan rates or application rates: the unemployment rate in 1930 and higher shares of Democratic and Roosevelt votes in 1932. We take this as evidence that HOLC was successful in not becoming either a general relief program or an instrument of patronage. Note as well that the political variables as a group explain small shares of the overall variability in either the application or acceptance rate (refer to the F-stats).

We close the discussion of HOLC allocations by focusing on the results for the HOLC office variables separately, as they will prove crucial to the identification of HOLC's impacts in the next section. Having an HOLC office increases a county's application, acceptance and loan rates. Interestingly, though, the nearest HOLC office being outside the county but less than 15 miles away or between 15 and 30 miles away had a strong impact on acceptance and loan rate but not application rate. ${ }^{23}$ This result is important and interesting for two reasons. First, it indicates that spatial segmentation in the mortgage market of lending operated more through supply than demand - the costs to HOLC of on-site appraisals and filing loan documents were greater for loans that were made in more distant counties. Second, the

\footnotetext{
${ }^{23}$ Note also the non-monotonic relationship between distance and acceptance rates: counties within 15 miles of the nearest HOLC office actually had a higher acceptance rate ceteris paribus than counties containing an HOLC office. One possible explanation is that, because of the higher application rates in counties with an HOLC office, these applications were on average weaker than those from surrounding counties, leading to more rejections.
} 
impact that these costs had on HOLC treatment levels is plausibly exogenous and provides an avenue through which we can identify the impacts of HOLC loan activity on local housing outcomes.

\section{HOLC's Impacts on Local Housing Markets}

We next turn to an evaluation of the effectiveness of HOLC intervention in stabilizing the housing market. An OLS estimator of the relationship between percentage of homes refinanced by HOLC and housing market outcomes would likely be biased downward since HOLC loans were distributed disproportionately to areas facing the greatest housing market and overall distress, as shown in the preceding section. We therefore estimate HOLC's impact with two-stage instrumental variables models in which the first stage predicts HOLC treatment intensity using an equation similar to (1) and the second examines the relationship between treatment intensity and 1940 non-farm home values and ownership rates, as well as new non-farm housing units from 1935 to 1940 . Identification requires one or more regressors from (1) that can be excluded from the second stage, meaning that, conditional on the controls, they must only be correlated with post-HOLC home values, ownership rates, and new building through their effect on HOLC treatment. Of the independent variables that strongly predicted loan rates in the preceding section, the three HOLC office variables - whether the nearest HOLC office was located in the county, outside the county but less than 15 miles away, or 15 to 30 miles away - are the most plausible candidates to satisfy such an exclusion restriction.

However, the non-random nature of HOLC office locations poses a potential problem for such an identification strategy: offices may have been placed in areas facing the greatest housing market distress. This could have occurred for two distinct reasons. First, HOLC administrators generally placed offices in large cities, and it appears that the Great Depression impacted housing markets in large cities more severely than in other areas. Specifically, the correlation between county population in 1930 and our measure of housing market distress - percentage change in new building between 1925-29 and 1930-34 is a highly significant -0.25 . Second, conditional on population HOLC administrators could have 
intentionally placed offices in the most distressed areas in an effort to best meet the needs of homeowners and lenders. These phenomena may lead to a downward bias if all three office variables are used as instruments. The controls for population, population density, percent urban, distress and 1930 housing market conditions would mitigate the extent of the bias but may not eliminate it completely.

Fortunately, our indicator of nonfarm housing market distress - percentage change in new building during the early stages of the depression - allows us to test whether HOLC offices were indeed placed in areas in which housing markets were the most troubled. We begin by computing correlations between percentage change in new building from 1925-29 to 1930-34 and each of the three distance from HOLC office variables. The correlation between percentage change in new building and whether the county contains an office is -0.22 and significant at the 0.01 percent level. This strong relationship is not surprising given the preceding discussion. Interestingly, though, the correlations for the other two office variables are much smaller. The correlation between percentage change in new building and whether the nearest office is outside the county but less than 15 miles away is -0.04 and significant at only the 5 percent level despite the large sample. The correlation between percentage change in new building and whether the nearest office is 15 to 30 miles away is a statistically insignificant -0.01 .

In Figure 1 we display kernel density functions for percentage change in new building, stratified by nearest HOLC office location. These plots reveal a similar story. The kernel density function for counties with an office lies well to the left of the function for the "control group" of counties whose nearest office is more than 30 miles away. The kernel density functions for counties whose nearest office is less than 15 miles away and those whose nearest office is 15 to 30 miles away, however, are similar to that of the control group in shape and value at which the function is maximized. ${ }^{24}$ The correlations and kernel density plots therefore suggest that HOLC offices were indeed located in counties facing the most housing market distress, but that the degree to which this relationship spilled over into surrounding areas was minimal. Consequently, the under 15 and 15-30 mile groups are the most appropriate comparison

\footnotetext{
${ }^{24}$ The kernel density functions for these groups are less smooth and have a narrower range than the kernel density function of the control group, but this is likely because the control group is much larger (2,373 counties).
} 
groups for the over 30 mile control group, while the counties containing an office form a less appropriate comparison group.

With this in mind, we estimate three instrumental variables models using two-stage least squares.

In each, the first stage regression is:

$$
\begin{aligned}
\text {HOLC }_{i}= & \beta_{0}+\beta_{1} \text { DEMO }_{i}+\beta_{2} \text { ECON }_{i}+\beta_{3} \text { INC }_{i}+\beta_{4} \text { DISTRESS }_{i}+\beta_{5} \text { POL L }_{i} \\
& +\beta_{6} \text { HOUS }_{i}+\beta_{7} \text { OFFICE }_{i}+\beta_{8} \Delta D E M O_{i, 1940}+\beta_{9} \Delta \text { COON }_{i, 1940}+\varepsilon_{i} .
\end{aligned}
$$

The three second stage regressions are

$$
\begin{aligned}
& Y_{i, 1940}=\gamma_{0}+\gamma_{1} \widehat{H O L C}_{i}+\gamma_{2} \text { DEMO }_{i}+\gamma_{3} \text { ECON }_{i}+\gamma_{4} I N C_{i}+\gamma_{5} \text { DISTRESS }_{i}+\gamma_{6} \text { POL }_{i} \\
& +\gamma_{7} \mathrm{HOUS}_{i}+\gamma_{8} \Delta \mathrm{DEMO}_{i, 1940}+\gamma_{9} \Delta \mathrm{ECON}_{i, 1940}+\mu_{i} \\
& Y_{i, 1940}=\gamma_{0}+\gamma_{1} \widehat{H O L C}_{i}+\gamma_{2} \text { DEMO }_{i}+\gamma_{3} \text { ECON }_{i}+\gamma_{4} \text { INC }_{i}+\gamma_{5} \text { DISTRESS }_{i}+\gamma_{6} \text { POL }_{i} \\
& +\gamma_{7} \text { HOUS }_{i}+\gamma_{8} \Delta \text { DEMO }_{i, 1940}+\gamma_{9} \Delta \text { ECON }_{i, 1940}+\gamma_{10} I N_{-} \text {COUNTY }_{i}+\mu_{i} \\
& Y_{i, 1940}=\gamma_{0}+\gamma_{1} \widehat{H O L C}_{i}+\gamma_{2} \text { DEMO }_{i}+\gamma_{3} \text { ECON }_{i}+\gamma_{4} \text { INC }_{i}+\gamma_{5} \text { DISTRESS }_{i}+\gamma_{6} \text { POL }_{i} \\
& +\gamma_{7} \text { HOUS }_{i}+\gamma_{8} \Delta D E M O_{i, 1940}+\gamma_{9} \Delta \text { ECON }_{i, 1940}+\gamma_{10} I N_{-} \text {COUNTY }_{i} \\
& +\gamma_{11} \text { DIS } 1_{i}+\mu_{i}
\end{aligned}
$$

where (3) excludes all three office variables as instruments, (4) excludes the under 15 and 15-30 mile distance variables (DIS1 and DIS2) but not the variable for whether there is an office in the county (IN_COUNTY), and (5) excludes DIS2 but not IN_COUNTY or DIS1. In this section, HOLC represents the percentage of nonfarm housing units refinanced with HOLC loans in each county. This is the dependent variable from the preceding section that best measures the extent to which a county was "treated" by the program. The second stage dependent variable $Y$ is the natural logarithm of non-farm median home value, the non-farm home ownership rate, or the natural logarithm of non-farm new housing units built from 1935 to 1940. Since HOUS includes 1930 home values and ownership rates and new building in 1925-1929, the second stage is a lagged dependent variable model that corrects for time- 
invariant sources of endogeneity bias. ${ }^{25}$ We include the changes in the demographic and economic structure variables between 1930 and 1940 (represented by $\triangle D E M O$ and $\triangle E C O N$ ) since the outcome variables in the second stage regression are measured in 1940. We do not include changes in the other independent variables, such as the income and distress measures, since their values in 1940 are potentially functions of HOLC treatment. ${ }^{26}$ We omit state fixed effects for now to allow the substantial betweenstate variation in the number of offices that resulted from the states' autonomy in administering the program to increase the explanatory power of our instruments. ${ }^{27}$ We later add them as a robustness check.

In (3), the parameter of interest $\gamma_{1}$ is identified under the assumption that distance from the nearest HOLC office is uncorrelated with unobservable characteristics that impacted housing markets during the 1930s. In (4), the identifying assumption is that distance from the nearest office is uncorrelated with these unobservable characteristics conditional on the county not having an office. The identifying assumption in (5) is that distance is uncorrelated with these unobservables conditional on there not being an office within 15 miles. Given the aforementioned correlations and kernel density plots, we suspect that the identifying assumption is more likely to hold in (4) and (5) than in (3). In it conceivable,

of course, that the controls might capture the potential sources of bias in (3), making IN_COUNTY a valid instrument. Our suspicion, though, is that the key differences in observables between the IN_COUNTY group and the control group suggest that there are likely key differences in unobservables as well.

Table 4 reports the results for each of the three dependent variables. The column labeled OLS displays the results from an OLS version of (3), while the columns labeled IV (1), IV (2), and IV (3)

\footnotetext{
${ }^{25}$ Because of the lagged dependent variables, the estimates are identical if we use changes in the dependent variables instead of levels. Our model can therefore alternatively be interpreted as a differences model that also includes lagged levels.

${ }^{26}$ Conceivably, the values of the demographic and economic structure variables in 1940 could also depend on HOLC treatment. Results are virtually identical if we do not include changes in these variables.

${ }^{27}$ To illustrate, a diverse group of states (California, Connecticut, Florida, Indiana, New Mexico, New Jersey and Virginia) had the greatest number of state and district offices (between 7 and 9). Other states opted for a more centralized structure, with two (Arizona and Idaho) having only a single office.
} 
represent the three aforementioned instrumental variables models. Our preferred specifications IV (2) and

IV (3) control for IN_COUNTY instead of using it as an instrument, while IV (3) controls for DIS1 as well. We display the coefficient estimates for HOLC loan rate in the second stage. When applicable, we also report the Kleibergen-Paap F statistic from a test of the joint significance of the instruments in the first stage, along with the p-value from the overidentification test. Finally, we conduct Hausman tests of the consistency of the OLS and IV (1) estimators relative to the preferred IV (2) estimator; we do not report the results in the table but discuss them below.

\section{[INSERT TABLE 4 ABOUT HERE.]}

Panel A of Table 4 displays the results for median home values. In the OLS regression, HOLC loan rate is statistically significant at the 10 percent level but its effect is minimal. Using all three office variables as instruments, loan rate becomes significant and its effect is larger: each percentage point increase is associated with an increase in median home value of approximately 3.5 percent. In our preferred specifications, the effect is an even larger 7.2-8.5 percent, implying that an additional standard deviation of HOLC lending raised the average county's median home value by 19-22 percent. Hausman tests reject the consistency of both the OLS estimator and the IV estimator with all three office variables as instruments, confirming our predictions that both would suffer from a downward bias. The overidentification test rejects the null hypothesis that the set of instruments is valid when all three office variables are used as instruments, but fails to reject the null when DIS1 and DIS2 are the only instruments. The F statistics are large enough to rule out weak instrument bias using a maximum acceptable bias of 5 percent in IV (1), 20 percent (barely missing the cutoff point for 15 percent) in IV (2), and 15 percent in IV (3).

Panel B reports the results for home ownership rate. The coefficient estimate for HOLC loan rate is essentially zero in both naïve specifications. However, in the preferred specifications the effect is large and statistically significant: a one percentage point increase in loan rate is associated with a 1.3-1.5 percentage point increase in home ownership rates. Importantly, the estimates are greater than 1 , meaning 
that the HOLC preserved more than one homeowner for every home it refinanced. The magnitudes imply that an additional standard deviation of HOLC lending increased the average county's home ownership rate by 3.4-3.9 percentage points. Again, Hausman tests reject the consistency of both naïve estimators while the overidentification test rejects the null when all three office variables are used as instruments but not when only DIS1 and DIS2 are used. The F statistics are virtually identical to those from the median home value regressions, differing only because of the slightly larger sample size.

Panel C shows the results for new building. The estimated effect of HOLC loan rate in the OLS regression is negative and significant, but the magnitude is small. A one percentage point increase in loan rate is associated with a 1.3 percent reduction in new building, which would translate to only a 0.15 percent reduction in overall housing stock based on the sample means for new building and number of housing units. In all three IV regressions, loan rate is insignificant and its effect remains small. The evidence is therefore consistent with HOLC having a minimal effect on housing production. Since all four estimates are close to zero, neither the Hausman nor overidentification tests reject the null hypothesis in any regression. The first stage F statistics are identical to those for homeownership rates as the sample is the same.

\section{$\underline{\text { Robustness Checks }}$}

To assess the sensitivity of our results we report results from a variety of robustness checks in

Table 5. In all cases we present estimates from the regressions that use both DIS1 and DIS2 as

instruments, although similar estimates are obtained if only DIS2 is used for this purpose. Panel A of the table reports the impact of adding three additional sets of control variables. First, we include per capita spending on five New Deal programs besides HOLC with possible links to housing markets to determine if our base estimates of HOLC impacts confound the effect of other New Deal programs. ${ }^{28}$ Second, we

\footnotetext{
${ }^{28}$ The five are Federal Housing Administration loans insured, relief and public works grants, Reconstruction Finance Corporation loans, Agricultural Adjustment Administration grants, and farm loans. These variables, which were graciously shared by Price Fishback, are the New Deal controls used by Fishback et al. (2010).
} 
add state fixed effects to ensure that unobservable state-level characteristics are not biasing our estimator. Finally, we also test whether our results are spuriously driven by patterns of county-specific shocks by controlling for the changes in each of the dependent variables within the farm portion of each county during the 1930s. ${ }^{29}$ Since HOLC was exclusively a program for nonfarm homeowners, changes in the farm sector should proxy (albeit imperfectly) for specific locational shocks that would have impacted the nonfarm housing sector even without HOLC intervention. None of these additional controls lead to statistically significant changes in the results reported for our base specification.

The pattern of our results also does not change when we consider several alternative functional forms (see panel B). We first employ alternative methods of measuring distance from the nearest HOLC office. We split the 30 miles outside the county into three 10 mile distance dummies instead of two 15 mile dummies. We also consider a linear instead of discrete distance specification within the 30 mile range by including a single 30 mile distance dummy plus the interaction of this dummy with linear distance. Next, we experiment with more flexible specifications for population, population density and percent urban. HOLC offices were disproportionately located in large, dense urban areas, so it is important to verify the results are not sensitive to different functional forms for the control variables that measure these influences. We model these three variables using sets of 10 dummies, representing population and population density deciles and 10 percent increments of percent urban. We also report estimates from specifications in which treatment levels are measured by either the proportion of owned homes (instead of all homes) refinanced by HOLC or the per capita dollar measure of HOLC lending employed by FLHKT. Finally, we use the levels rather than the logs of median home values (1930 and 1940) and new home construction (1925-29, 1930-34, and 1935-40).

\footnotetext{
${ }^{29}$ Specifically, when using the natural logarithm of non-farm median home value in 1940 as the dependent variable, we control for the change in the natural logarithm of the value of the average farm building between 1930 and 1940. Average farm building value is the closest analog to median non-farm home value available in the data. When nonfarm home ownership rate in 1940 is the dependent variable, we include change in farm ownership rate from 1930 to 1940. When the natural logarithm of new non-farm dwellings from 1935-1940 is the dependent variable, we include change in the natural logarithm of new farm dwellings from 1925-1929 to 1935-1940.
} 
In Panel $\mathrm{C}$ of Table 5 we show the results are also robust to weighting by the natural log of population and the natural log of nonfarm housing units. Weighting allows the estimated coefficients to reflect average effects across the entire country as opposed to effects in the average county. Weighting would reduce the magnitude of the estimates if the effect is weakest in large urban areas, and vice versa. The fact that weighting does not affect the results suggests that there is not substantial heterogeneity in the treatment effect, at least among the counties without an HOLC office that we rely on for identification.

Next, we verify in Panel D that our conclusions are robust to alternative methods of sample construction. Recall that our preferred specifications control for whether the county contained an office, restricting the identifying variation to the counties that did not contain an office. We consider an alternative approach to doing this by simply dropping the counties in which offices were located from the sample. We also estimate a model that drops all counties within 15 miles of an office, leaving DIS2 as the only instrument.

Together, the results reported in Panels A, B, C, and D of Table 5 provide strong evidence that our results are not sensitive to minor specification changes. In all of these regressions, HOLC loan rate has a positive and significant impact on median home value and the homeownership rate but an insignificant effect on new building activity. Excluding the three regressions which yield incomparable magnitudes due to differences in scale (alternate HOLC rate, amount of HOLC loans per capita, and levels instead of logs), all of the results indicate that a one percentage point increase in loan rate increases median home value by 7-12 percent and home ownership rate by 1.3-2.2 percentage points. We next turn to a discussion of the final panel of Table 5, which reports the results from utilizing artificial HOLC office locations. It turns out that these results not only help establish robustness, they also shed light on the broader assessment of HOLC program effects. 
Artificial Offices, Large Urban Markets and Identifying the Impacts of the HOLC

In this section we tie our results together with those of FLHKT in order to provide a clear picture of what we have and have not learned about the impacts HOLC had on local housing markets during the Great Depression. Like us, FLHKT both exploit distance from HOLC offices in their identification strategy and recognize the potential endogeneity of these office locations. Whereas we account for this potential endogeneity by controlling for whether the county has an office, their proposed solution is to use "artificial" instead of actual office locations. Noting that HOLC offices were typically placed in large cities, they place an artificial office in each state's capital and four most heavily populated counties, and then create the instrument by computing distances from these artificial locations. Constructing artificial office locations using pre-depression characteristics such as size should indeed correct for bias from HOLC administrators deliberately placing offices in counties facing the greatest housing market distress. However, placing artificial offices in large counties leaves this approach susceptible to bias from large counties experiencing different housing market shocks than other areas in the 1930s for reasons aside from HOLC. The controls should mitigate the extent of this bias but may not eliminate it completely. In this section, we consider two variations of the artificial HOLC office approach. The first specification (referred to as "Artificial Offices 1") duplicates the artificial office locations used by FLHKT: each state's capital and four largest counties. The second specification (“Artificial Offices 2") offers our own method of constructing artificial office locations. We first estimate a probit model with IN_COUNTY as the dependent variable and county characteristics from 1920 - before both the 1920s boom and 1930s bust - as the independent variables. These 1920 variables include the set of demographic characteristics plus dummy variables for the state capital and the five most heavily populated counties in the state. We then assign offices to the 209 counties with the highest predicted probabilities, subject to the constraint that every state has at least one office. This method correctly predicts 147 of the 209 actual office locations, while FLHKT's artificial office approach correctly predicts 138. We then construct distances from the nearest artificial HOLC office, using the same 
divisions as before: in the county, outside the county but within 15 miles, within 15-30 miles, and beyond 30 miles.

As with actual offices, a key to assessing a priori the validity of these artificial office approaches is the relationship between proximity to artificial office locations and our measure of nonfarm housing market distress - the percentage change in new building from 1925-29 to 1930-34. Using “Artificial

Offices 1," the correlation between IN_COUNTY and percentage change in new building from 1925-29 to 1930-34 is -0.19 and significant at the 0.01 percent level. The correlations between change in new

building and DIS1 and DIS2, however, are both only -0.03 and insignificant at the 5 percent level. Using "Artificial Offices 2," the correlation between change in new building and IN_COUNTY is a significant 0.24, while the correlations between change in new building and DIS1 and DIS2 are both an insignificant -0.03. Accordingly, the kernel density plots in Figures 2 and 3 both show that the distress distribution for counties with an artificial office lies to the left of the distributions for the other three groups of counties. The correlations and kernel density plots therefore point to the same conclusion reached with actual offices: relative to the "control group" of counties whose nearest artificial HOLC office is more than 30 miles away, counties whose nearest artificial office is within 15 miles (but not in the county) or 15-30 miles away are more appropriate comparison groups than counties that contain an artificial office.

Panel E of Table 5 displays the results from 1) regressions that utilize all three distance from artificial office variables as instruments and 2) regressions that use IN_COUNTY as a control and DIS1 and DIS2 as instruments. The correlations and kernel density plots suggest that the results from the regressions controlling for $I N \_C O U N T Y$ will be more reliable. Indeed, the patterns observed are strikingly similar to those obtained using actual offices. With all three distance variables as instruments, HOLC loan rate has a small effect on home values and no effect on home ownership rates or new building. With $I N \_C O U N T Y$ as a control, HOLC loan rate has a larger effect on home values and a positive effect on home ownership rates, though still no effect on new building. The fact that both actual 
and artificial offices lead to the same pattern suggests that the bias observed with actual office locations more likely reflects differential shocks in large urban markets than the intentional placement of offices in distressed areas.

At this point, we can combine our results with those of FLHKT to form a summary of what we know and do not know about HOLC's role in stabilizing home values and home ownership. Importantly, both papers agree that HOLC increased housing values and home ownership (stock of owned homes in their case, ownership rate in ours) once the few hundred largest counties are excluded from the sources of identifying variation. We prevent the largest counties from providing identifying variation by controlling for whether counties had an actual or artificial HOLC office, while FLHKT do this by simply dropping the 394 counties with over 50,000 residents from the sample. The evidence therefore indicates that HOLC successfully repaired credit channels and prevented further disruptions in the housing and mortgage markets in most counties.

We also agree with FLHKT that, once the largest counties are allowed to provide identifying variation, HOLC's estimated impacts are weakened dramatically. FLHKT conjecture that the different impacts estimated for the full and small-county samples are due to heterogeneity in impacts across the sample. The failure of an individual mortgage lender may have been more catastrophic in small markets because good substitutes were not readily available. In contrast, we argue - based on the regression results plus the observation that counties with an actual or artificial office faced the greatest housing market distress in the early stages of the depression - that distance-based instrumental variable approaches are not appropriate to identify HOLC's impacts in the largest counties.

Our results combined with those of FLHKT point to the need for future research to examine HOLC's impacts in the largest counties. Large urban markets took the brunt of the mortgage crisis in terms of average decreases in home values, homeownership rates and housing production — and many of them suffered from large numbers of failed mortgage lending institutions. They also received a disproportionately large share of HOLC funds. In our data only 7 percent of counties contained an HOLC 
office, but together they received 58 percent of all HOLC loans. Understanding HOLC's impacts in these areas is therefore an important part of the HOLC story.

\section{Conclusion}

The Home Owner's Loan Corporation was created during FDR's first hundred days - at the nadir of the deepest housing crisis in American history. In less than two years the HOLC assembled a nationwide home mortgage lending network and made long-term, amortized loans on more than a million homes. The goal was to break the self-reinforcing cycle of foreclosure, forced property sales and decreases in home values by creating the nation's most patient, and largest, home mortgage lender and by removing toxic mortgage loans off the balance sheets of private lenders so that they could resume lending and help stabilize the mortgage market on their own.

The purpose of this paper is to characterize how HOLC loan activity was allocated across local housing markets, and how well it worked. The evidence indicates that both homeowners and the agency's staff viewed HOLC as a targeted housing program rather than a general assistance program, and that its lending activities were concentrated in local markets where economic and housing market distress was the greatest. Our IV estimates, moreover, provide evidence that HOLC lending worked as intended. HOLC activity led to increases in median home values and homeownership rates, but had no significant impact on the level of new home building. We take this as evidence that HOLC repaired mortgage credit channels and shut off the destructive foreclosure — housing value — delinquency cycle without stimulating new production in markets where the housing stock was, if anything, in surplus. A limitation of our IV analysis, however, is that endogeneity concerns force us to exclude the largest counties from the sources of identifying variation, leaving HOLCs impacts in these areas as an important direction for future research.

An additional topic that deserves further investigation is the role of the New Deal in contributing to the recovery in housing production during the late 1930s. The 1920s boom in homebuilding left an uneven spatial pattern of housing surpluses due to different secular trends in rates of household formation 
across regions and city-sizes. Our findings suggest HOLC had little to do with where and how fast housing production recovered in the late 1930s. However, other New Deal programs were explicitly designed to stimulate new home building. The FHA loan insurance program was heavily used by mortgage companies, commercial banks and life insurance companies, while the modern S\&L industry arose with the support of the FHLB discount system, federal S\&L charters and FSLIC deposit insurance. It is important to assess whether and how well these stimulants to home building worked if we are to fully understand the impact of New Deal interventions on the housing and mortgage crisis of the 1930s. 


\section{References}

Ben Bernanke. "Nonmonetary Effects of the Financial Crisis in the Propagation of the Great Depression." American Economic Review, Vol. 73(3), 1983, 257-76.

Bernanke, Ben S. (2009). "The Crisis and the Policy Response," The Stamp Lecture, London School of Economics, London, England, January 13, 2009

Ergungor, O. Emre (2007). "On the Resolution of Financial Crises: The Swedish Experience,” Policy Discussion paper No. 21, Federal Reserve Bank of Cleveland, June.

Federal Home Loan Bank Board (1934). “Operations of the Home Owners' Loan Corporation,” U.S. Senate Document No. 145, 73 Congress, $2^{\text {nd }}$ Session, February 20, 1934.

Federal Home Loan Bank Board. Annual Report of the Federal Home Loan Bank Board. Various years. Washington: Government Printing Office, 1934-40.

Fishback, Price, Shawn Kantor and John Wallis, (2003) "Can the New Deal's Three R's Be Rehabilitated? A Program-by-Program, County-by-County Analysis," with Shawn Kantor and John Wallis. Explorations in Economic History , October): 278-307.

Fishback, Price, Alfonso Flores Lagunes, William C. Horrace, Shawn Kantor, and Jaret Treber (2010). "The Influence of the Home Owners' Loan Corporation on Housing Markets During the 1930s."

Grebler, Leo, David M. Blank, and Louis Winnick, Capital Formation in Residential Real Estate: Trends and Prospects (Princeton, NJ: Princeton University Press, 1956).

Gries, John M. and James Ford, eds. (1932). Home Finance and Taxation (Washington, D.C.: National Capital Press, Inc).

Haines, Michael. Historical, Demographic, Economic, and Social Data: The United States, 1790-2000, Computerized data tapes from ICPSR.

Harriss, C. Lowell (1951). History and Policies of the Home Owners' Loan Corporation, National Bureau of Economic Research Financial Research Program: Studies in Urban Mortgage Financing (New York: National Bureau of Economic Research, Inc. 1951).

Frederic Mishkin (1978). "The Household Balance Sheet and the Great Depression." The Journal of Economic History, Vol. 38, No. 4 (Dec., 1978), pp. 918-937

Rose, Jonathan D. "The Incredible HOLC? Mortgage Relief During the Great Depression. Unpublished working paper, Board of Governors, Federal Reserve, November 2009.

Snowden, Kenneth (1997). "Building and Loan Associations in the US, 1880-1893: the Origins of Localization in the Residential Mortgage Market," Research in Economics, 51, 227-50.

Snowden, Kenneth (2003). "The Transition from Building and Loan to Savings and Loan," in S. Engerman, P. Hoffman, J. Rosenthal and K. Sokoloff (eds.), Finance, Intermediaries and Economic Development, Cambridge, 157-206. 
Snowden, Kenneth (2009). "The Anatomy of a Residential Mortgage Crisis: A Look Back to the 1930s."

Tough, Rosalind (1951). "The Life Cycle of the Home Owners' Loan Corporation," Land Economics, Vol. 27, No. 4 (Nov.), pp. 324-331.

Wheelock, David (2008). "The Federal Response to Home Mortgage Distress: Lessons from the Great Depression." Federal Reserve Bank of St. Louis Review.

U.S. Bureau of the Census, Sixteenth Census of the United States: 1940, Housing (Washington, DC: GPO, 1943).

U.S. Housing and Home Finance Agency (1952). Final Report : Home Owners' Loan Corporation, $1933-$ 1951. Washington, D.C.

U.S. Federal Home Loan Bank Board (1933-40). Annual Reports. Washington, D.C. 
Table 1 - Mortgages Held by Major Lending Groups on 1-4 Family Non-Farm Homes and Purchased by HOLC, 1930-1940 (\$ millions)

\begin{tabular}{lccccc}
\hline \hline & $\begin{array}{c}\text { B\&L to } \\
\text { S\&L }\end{array}$ & $\begin{array}{c}\text { Mutual } \\
\text { Savings } \\
\text { Banks }\end{array}$ & $\begin{array}{c}\text { Commercial } \\
\text { Banks }\end{array}$ & $\begin{array}{c}\text { Insurance } \\
\text { companies }\end{array}$ & $\begin{array}{c}\text { Others \& } \\
\text { Individuals }\end{array}$ \\
\hline Mortgages Held in 1930 & 6149 & 2341 & 2212 & 1838 & 6457 \\
Change 1930-33 & -1676 & +13 & -311 & -136 & -1561 \\
$\begin{array}{l}\text { Change 1933-36 } \\
\text { Home Mortgages }\end{array}$ & -1216 & -272 & -183 & -382 & -545 \\
$\begin{array}{l}\text { Purchased by HOLC } \\
\text { 1933-1936 }\end{array}$ & {$[\mathbf{7 7 0}]$} & {$[\mathbf{4 1 0 ]}$} & {$[\mathbf{5 2 5}]$} & {$[\mathbf{1 6 5}]$} & {$[\mathbf{8 8 0}]$} \\
\hline $\begin{array}{l}\text { Change 1936-40 } \\
\text { Mortgages Held in 1940 }\end{array}$ & +816 & +80 & +668 & +518 & +686 \\
\hline
\end{tabular}

Source: Grebler, 1956, N-4; U.S. Housing and Home Finance Agency (1952), iv. 
Table 2 - Summary Statistics

\begin{tabular}{|c|c|c|c|c|}
\hline & & FKW & Year & Mean (S. Dev.) \\
\hline \multirow[t]{4}{*}{ HOLC } & Application Rate & - & $1933-36$ & $14.0(8.2)$ \\
\hline & Acceptance Rate & - & $1933-36$ & $48.3(14.9)$ \\
\hline & Loan Rate 1 (base is owned nonfarm units) & & $1933-36$ & $7.3(5.3)$ \\
\hline & Loan Rate 2 (base is nonfarm units) & - & $1933-36$ & $3.6(2.6)$ \\
\hline \multirow[t]{12}{*}{ Demographic } & Population & YES & 1930 & $38857(122646)$ \\
\hline & Density (hundreds of people/square mile) & YES & 1930 & $0.9(6.5)$ \\
\hline & Percent Urban & YES & 1930 & $21.6(24.9)$ \\
\hline & Percent Black & YES & 1930 & $11.1(18.3)$ \\
\hline & Percent Non-White and Non-Black & NO & 1930 & $2.4(8.3)$ \\
\hline & Percent Illiterate & YES & 1930 & $5.4(5.8)$ \\
\hline & Percent Married & NO & 1930 & $61.5(3.4)$ \\
\hline & Percent Female & NO & 1930 & $48.4(2.1)$ \\
\hline & Percent 25 to 44 & NO & 1930 & $25.9(3.2)$ \\
\hline & Percent 45 to 64 & NO & 1930 & $16.9(3.3)$ \\
\hline & Percent Over 65 & NO & 1930 & $5.8(2.2)$ \\
\hline & Percent Foreign Born & NO & 1930 & $4.8(5.9)$ \\
\hline Economic & Average Farm Size & YES & 1929 & $289.3(874.4)$ \\
\hline \multirow[t]{4}{*}{ Structure } & Percent Farmland & YES & 1929 & $64.9(27.3)$ \\
\hline & Percent Manufacturing & NO & 1930 & $8.5(10.9)$ \\
\hline & Percent Wholesale & NO & 1930 & $1.3(1.7)$ \\
\hline & Percent Retail & NO & 1930 & $5.0(2.7)$ \\
\hline \multirow[t]{2}{*}{ Income } & Tax Returns Per Capita & YES & 1929 & $1.4(1.3)$ \\
\hline & Retail Sales Per Capita & YES & 1929 & $549.3(265.2)$ \\
\hline \multirow[t]{4}{*}{ Distress } & Percentage Change in Retail Sales & YES & $1933-1929$ & $-47.5(23.0)$ \\
\hline & Unemployment Rate & YES & 1930 & $2.8(2.2)$ \\
\hline & Percent Farm Failures & YES & 1929 & $3.1(3.7)$ \\
\hline & Percentage Change in New Building & NO & $\begin{array}{c}1925-29 \text { to } \\
1930-34\end{array}$ & $-25.1(56.2)$ \\
\hline \multirow[t]{5}{*}{ Political } & Percent Democrat & YES & $1896-1928$ & $49.3(18.4)$ \\
\hline & Percent Roosevelt - Percent Democrat & YES & 1932 & $18.7(10.3)$ \\
\hline & Standard Deviation Percent Democrat & YES & $1896-1932$ & $11.6(4.8)$ \\
\hline & Voting Rate & YES & 1932 & $31.6(15.0)$ \\
\hline & Tenure in House of Representatives & YES & 1933 & $52.1(64.6)$ \\
\hline \multirow{6}{*}{$\begin{array}{l}\text { Housing } \\
\text { (all nonfarm) }\end{array}$} & Median Home Value (Pre-HOLC) & NO & 1930 & $2561(1283)$ \\
\hline & Median Home Value (Post-HOLC) & NO & 1940 & $1624(898)$ \\
\hline & Home Ownership Rate (Pre-HOLC) & NO & 1930 & $50.7(11.5)$ \\
\hline & Home Ownership Rate (Post-HOLC) & NO & 1940 & $47.4(9.9)$ \\
\hline & New Building (Pre-HOLC) & NO & 1925-1929 & $1202(7178)$ \\
\hline & New Building (Post-HOLC) & NO & 1935-1939 & $786(3095)$ \\
\hline \multirow[t]{3}{*}{ Distance } & HOLC Office in County & NO & 1934 & $0.070(0.255)$ \\
\hline & $0<$ Distance to HOLC Office $\leq 15$ & NO & 1934 & $0.021(0.142)$ \\
\hline & $15<$ Distance to HOLC Office $\leq 30$ & NO & 1934 & $0.139(0.346)$ \\
\hline
\end{tabular}


Table 3 - Determinants of HOLC Loan Activity

\begin{tabular}{|c|c|c|c|c|c|}
\hline & & $\begin{array}{c}\text { Application } \\
\text { Rate }\end{array}$ & $\begin{array}{l}\text { Acceptance } \\
\text { Rate }\end{array}$ & $\begin{array}{c}\text { Loan Rate } \\
\text { (1) }\end{array}$ & $\begin{array}{l}\text { Loan Rate } \\
\text { (2) }\end{array}$ \\
\hline \multirow[t]{12}{*}{ Demographic } & $\ln$ (Population) & $\begin{array}{c}-1.776 \\
(0.323)^{* * *}\end{array}$ & $\begin{array}{l}0.705 \\
(0.737)\end{array}$ & $\begin{array}{c}-1.121 \\
(0.209)^{* * *}\end{array}$ & $\begin{array}{c}-0.588 \\
(0.105)^{* * *}\end{array}$ \\
\hline & Density & $\begin{array}{l}-0.016 \\
(0.014)\end{array}$ & $\begin{array}{l}-0.008 \\
(0.030)\end{array}$ & $\begin{array}{l}-0.012 \\
(0.011)\end{array}$ & $\begin{array}{l}-0.006 \\
(0.004)\end{array}$ \\
\hline & Percent Urban & $\begin{array}{c}0.032 \\
(0.010)^{* * *}\end{array}$ & $\begin{array}{c}0.047 \\
(0.021)^{* *}\end{array}$ & $\begin{array}{c}0.030 \\
(0.007) * * *\end{array}$ & $\begin{array}{c}0.015 \\
(0.003)^{* * *}\end{array}$ \\
\hline & Percent Black & $\begin{array}{c}0.059 \\
(0.016)^{* * *}\end{array}$ & $\begin{array}{c}0.044 \\
(0.034)\end{array}$ & $\begin{array}{c}0.035 \\
(0.009)^{* * *}\end{array}$ & $\begin{array}{c}0.016 \\
(0.004)^{* * *}\end{array}$ \\
\hline & $\begin{array}{l}\text { Percent Non-White and } \\
\text { Non-Black }\end{array}$ & $\begin{array}{c}0.091 \\
(0.024)^{* * * *}\end{array}$ & $\begin{array}{c}0.161 \\
(0.056)^{* * *}\end{array}$ & $\begin{array}{c}0.043 \\
(0.016)^{* * *}\end{array}$ & $\begin{array}{c}0.012 \\
(0.007)^{*}\end{array}$ \\
\hline & Percent Illiterate & $\begin{array}{l}-0.081 \\
(0.046)^{*}\end{array}$ & $\begin{array}{l}-0.207 \\
(0.110)^{*}\end{array}$ & $\begin{array}{l}-0.056 \\
(0.029)^{*}\end{array}$ & $\begin{array}{l}-0.018 \\
(0.013)\end{array}$ \\
\hline & Percent Married & $\begin{array}{c}0.270 \\
(0.049)^{* * *}\end{array}$ & $\begin{array}{c}0.383 \\
(0.112)^{* * *}\end{array}$ & $\begin{array}{c}0.159 \\
(0.031)^{* * *}\end{array}$ & $\begin{array}{c}0.084 \\
(0.016)^{* * *}\end{array}$ \\
\hline & Percent Female & $\begin{array}{c}-0.353 \\
(0.116)^{* * *}\end{array}$ & $\begin{array}{l}-0.290 \\
(0.263)\end{array}$ & $\begin{array}{c}-0.281 \\
(0.078) * * *\end{array}$ & $\begin{array}{c}-0.147 \\
(0.038)^{* * *}\end{array}$ \\
\hline & Percent 25 to 44 & $\begin{array}{c}-0.313 \\
(0.082)^{* * *}\end{array}$ & $\begin{array}{c}-0.697 \\
(0.195)^{* * *}\end{array}$ & $\begin{array}{c}-0.212 \\
(0.053) * * *\end{array}$ & $\begin{array}{c}-0.133 \\
(0.026)^{* * *}\end{array}$ \\
\hline & Percent 45 to 64 & $\begin{array}{l}0.080 \\
(0.104)\end{array}$ & $\begin{array}{l}0.190 \\
(0.229)\end{array}$ & $\begin{array}{l}-0.011 \\
(0.066)\end{array}$ & $\begin{array}{c}-0.00006 \\
(0.034)\end{array}$ \\
\hline & Percent Over 65 & $\begin{array}{c}-1.273 \\
(0.153)^{* * *}\end{array}$ & $\begin{array}{c}-1.049 \\
(0.356)^{* * *}\end{array}$ & $\begin{array}{c}-0.668 \\
(0.097)^{* * *}\end{array}$ & $\begin{array}{c}-0.388 \\
(0.051)^{* * *}\end{array}$ \\
\hline & Percent Foreign Born & $\begin{array}{r}0.027 \\
(0.043)\end{array}$ & $\begin{array}{l}-0.079 \\
(0.089)\end{array}$ & $\begin{array}{l}-0.015 \\
(0.028) \\
\end{array}$ & $\begin{array}{r}0.005 \\
(0.015) \\
\end{array}$ \\
\hline \multirow[t]{5}{*}{$\begin{array}{l}\text { Economic } \\
\text { Structure }\end{array}$} & Average Farm Size & $\begin{array}{l}-0.0001 \\
(0.0002)\end{array}$ & $\begin{array}{c}0.0004 \\
(0.0009)\end{array}$ & $\begin{array}{c}-0.00003 \\
(0.0001)\end{array}$ & $\begin{array}{l}0.00002 \\
(0.00005)\end{array}$ \\
\hline & Percent Farmland & $\begin{array}{l}-0.004 \\
(0.007)\end{array}$ & $\begin{array}{c}0.004 \\
(0.017)\end{array}$ & $\begin{array}{l}0.0002 \\
(0.005)\end{array}$ & $\begin{array}{c}0.001 \\
(0.002)\end{array}$ \\
\hline & Percent Manufacturing & $\begin{array}{c}-0.044 \\
(0.013)^{* * *}\end{array}$ & $\begin{array}{c}0.020 \\
(0.031)\end{array}$ & $\begin{array}{c}-0.022 \\
(0.009)^{* *}\end{array}$ & $\begin{array}{l}-0.005 \\
(0.004)\end{array}$ \\
\hline & Percent Wholesale & $\begin{array}{l}0.086 \\
(0.070)\end{array}$ & $\begin{array}{l}-0.008 \\
(0.158)\end{array}$ & $\begin{array}{c}0.048 \\
(0.050)\end{array}$ & $\begin{array}{c}0.008 \\
(0.024)\end{array}$ \\
\hline & Percent Retail & $\begin{array}{c}0.356 \\
(0.148)^{* *}\end{array}$ & $\begin{array}{c}0.137 \\
(0.335)\end{array}$ & $\begin{array}{c}0.247 \\
(0.100)^{* *}\end{array}$ & $\begin{array}{c}0.146 \\
(0.050)^{* * *}\end{array}$ \\
\hline \multirow[t]{3}{*}{ Income } & Tax Returns Per Capita & $\begin{array}{c}-0.599 \\
(0.201)^{* * *}\end{array}$ & $\begin{array}{l}-0.042 \\
(0.427)\end{array}$ & $\begin{array}{c}-0.253 \\
(0.142)^{*}\end{array}$ & $\begin{array}{l}-0.101 \\
(0.069)\end{array}$ \\
\hline & Retail Sales Per Capita & $\begin{array}{l}-0.001 \\
(0.002)\end{array}$ & $\begin{array}{c}0.005 \\
(0.004) \\
\end{array}$ & $\begin{array}{c}-0.0002 \\
(0.001)\end{array}$ & $\begin{array}{r}-0.0003 \\
(0.0006) \\
\end{array}$ \\
\hline & & ontinued - & & & \\
\hline
\end{tabular}




\begin{tabular}{|c|c|c|c|c|c|}
\hline & & $\begin{array}{l}\text { Application } \\
\text { Rate }\end{array}$ & $\begin{array}{l}\text { Acceptance } \\
\text { Rate }\end{array}$ & $\begin{array}{l}\text { Loan Rate } \\
\text { (1) }\end{array}$ & $\begin{array}{l}\text { Loan Rate } \\
\text { (2) }\end{array}$ \\
\hline \multirow[t]{4}{*}{ Distress } & $\begin{array}{l}\text { Percentage Change Retail } \\
\text { Sales }\end{array}$ & $\begin{array}{c}-0.025 \\
(0.006)^{* * *}\end{array}$ & $\begin{array}{l}-0.023 \\
(0.014)\end{array}$ & $\begin{array}{c}-0.015 \\
(0.004)^{* * *}\end{array}$ & $\begin{array}{c}-0.008 \\
(0.002)^{* * *}\end{array}$ \\
\hline & Unemployment Rate & $\begin{array}{c}0.072 \\
(0.068)\end{array}$ & $\begin{array}{c}0.368 \\
(0.216)^{*}\end{array}$ & $\begin{array}{l}0.049 \\
(0.044)\end{array}$ & $\begin{array}{l}0.015 \\
(0.022)\end{array}$ \\
\hline & Percent Farm Failures & $\begin{array}{l}-0.049 \\
(0.032)\end{array}$ & $\begin{array}{l}-0.156 \\
(0.084)^{*}\end{array}$ & $\begin{array}{c}-0.055 \\
(0.019)^{* * *}\end{array}$ & $\begin{array}{c}-0.023 \\
(0.009)^{* * *}\end{array}$ \\
\hline & $\begin{array}{l}\text { Percentage Change New } \\
\text { Building }\end{array}$ & $\begin{array}{c}-0.009 \\
(0.003)^{* * *}\end{array}$ & $\begin{array}{c}-0.037 \\
(0.006)^{* * *}\end{array}$ & $\begin{array}{c}-0.008 \\
(0.002)^{* * *}\end{array}$ & $\begin{array}{c}-0.004 \\
(0.0009)^{* * *}\end{array}$ \\
\hline \multirow[t]{5}{*}{ Political } & Percent Democrat & $\begin{array}{l}0.003 \\
(0.013)\end{array}$ & $\begin{array}{c}0.065 \\
(0.033)^{* *}\end{array}$ & $\begin{array}{l}0.008 \\
(0.008)\end{array}$ & $\begin{array}{l}0.0006 \\
(0.004)\end{array}$ \\
\hline & $\begin{array}{l}\text { Percent Roosevelt - Percent } \\
\text { Democrat }\end{array}$ & $\begin{array}{l}-0.008 \\
(0.022)\end{array}$ & $\begin{array}{c}0.089 \\
(0.047)^{*}\end{array}$ & $\begin{array}{l}0.010 \\
(0.014)\end{array}$ & $\begin{array}{l}0.006 \\
(0.007)\end{array}$ \\
\hline & $\begin{array}{l}\text { Standard Deviation Percent } \\
\text { Democrat }\end{array}$ & $\begin{array}{c}-0.141 \\
(0.047)^{* * *}\end{array}$ & $\begin{array}{l}-0.092 \\
(0.106)\end{array}$ & $\begin{array}{c}-0.091 \\
(0.030) * * *\end{array}$ & $\begin{array}{c}-0.041 \\
(0.014)^{* * *}\end{array}$ \\
\hline & Voting Rate & $\begin{array}{l}0.039 \\
(0.027)\end{array}$ & $\begin{array}{l}0.050 \\
(0.069)\end{array}$ & $\begin{array}{l}0.017 \\
(0.017)\end{array}$ & $\begin{array}{l}0.008 \\
(0.009)\end{array}$ \\
\hline & $\begin{array}{l}\text { Tenure in House of } \\
\text { Representatives }\end{array}$ & $\begin{array}{l}0.0003 \\
(0.002)\end{array}$ & $\begin{array}{l}0.002 \\
(0.004)\end{array}$ & $\begin{array}{r}0.0009 \\
(0.001)\end{array}$ & $\begin{array}{l}0.0004 \\
(0.0006)\end{array}$ \\
\hline \multirow[t]{3}{*}{ Housing } & $\begin{array}{l}\ln (\text { Median Home Value) } \\
\text { (pre-HOLC) }\end{array}$ & $\begin{array}{c}6.004 \\
(0.444)^{* * *}\end{array}$ & $\begin{array}{c}9.911 \\
(1.098)^{* * *}\end{array}$ & $\begin{array}{c}3.927 \\
(0.285)^{* * *}\end{array}$ & $\begin{array}{c}1.876 \\
(0.133)^{* * *}\end{array}$ \\
\hline & $\begin{array}{l}\text { Home Ownership Rate (pre- } \\
\text { HOLC) }\end{array}$ & $\begin{array}{l}-0.006 \\
(0.018)\end{array}$ & $\begin{array}{c}0.187 \\
(0.038) * * *\end{array}$ & $\begin{array}{c}0.026 \\
(0.011)^{* *}\end{array}$ & $\begin{array}{c}0.076 \\
(0.006)^{* * *}\end{array}$ \\
\hline & $\begin{array}{l}\ln (\text { New Building) (pre- } \\
\text { HOLC) }\end{array}$ & $\begin{array}{c}1.919 \\
(0.212)^{* * *}\end{array}$ & $\begin{array}{l}-0.213 \\
(0.475)\end{array}$ & $\begin{array}{c}1.045 \\
(0.135)^{* * *}\end{array}$ & $\begin{array}{c}0.545 \\
(0.069)^{* * *}\end{array}$ \\
\hline \multirow[t]{13}{*}{ Office } & HOLC Office in County & $\begin{array}{c}2.713 \\
(0.534)^{* * *}\end{array}$ & $\begin{array}{c}2.160 \\
(0.910)^{* *}\end{array}$ & $\begin{array}{c}2.400 \\
(0.282)^{* * *}\end{array}$ & $\begin{array}{c}1.023 \\
(0.182)^{* * *}\end{array}$ \\
\hline & $\begin{array}{l}0<\text { Distance to HOLC } \\
\text { Office } \leq 15\end{array}$ & $\begin{array}{l}0.614 \\
(0.709)\end{array}$ & $\begin{array}{c}5.291 \\
(1.365)^{* * *}\end{array}$ & $\begin{array}{c}1.086 \\
(0.474)^{* *}\end{array}$ & $\begin{array}{c}0.669 \\
(0.266)^{* *}\end{array}$ \\
\hline & $\begin{array}{l}15<\text { Distance to HOLC } \\
\text { Office } \leq 30\end{array}$ & $\begin{array}{l}0.061 \\
(0.302)\end{array}$ & $\begin{array}{c}2.529 \\
(0.689) * * *\end{array}$ & $\begin{array}{c}0.368 \\
(0.186)^{* *}\end{array}$ & $\begin{array}{c}0.246 \\
(0.099)^{* *}\end{array}$ \\
\hline & State Fixed Effects & YES & YES & YES & YES \\
\hline & Observations & 2947 & 2942 & 2947 & 2947 \\
\hline & $\mathrm{R}^{2}$ & 0.568 & 0.414 & 0.576 & 0.573 \\
\hline & F Demographics & $21.55 * * *$ & $3.90 * * *$ & $18.01 * * *$ & $20.30 * * *$ \\
\hline & F Economic Structure & $4.21 * * *$ & 0.16 & $3.00 * *$ & $2.34 * *$ \\
\hline & F Income & $5.76 * * *$ & 1.06 & 1.82 & 1.53 \\
\hline & F Distress & $9.24 * * *$ & $14.16 * * *$ & $12.89 * * *$ & $11.83 * * *$ \\
\hline & F Political & $3.51 * * *$ & 1.15 & $3.00 * *$ & $2.34 * *$ \\
\hline & F Housing & $106.92 * * *$ & $35.63 * * *$ & $97.12 * * *$ & $136.61 * * *$ \\
\hline & F Distance & $8.70 * * *$ & $9.19 * * *$ & $14.09 * * *$ & $12.48 * * *$ \\
\hline
\end{tabular}

Notes: Heteroskedasticity-robust standard errors in parentheses. $* * *$ statistically significant at $1 \%$ level; ** 5\% level; * $10 \%$ level. 
Table 4 - Effects of HOLC Loan Activity

\begin{tabular}{lcccc}
\hline \hline & \multicolumn{2}{c}{ Naïve Specifications } & \multicolumn{2}{c}{ Preferred Specifications } \\
& OLS & IV (1) & IV (2) & IV (3) \\
\hline $\begin{array}{l}\text { Distance Variables: } \\
\text { As Instrumental Variables }\end{array}$ & -- & All & DIS1/DIS2 & Only DIS2 \\
As Controls & -- & -- & IN_COUNTY & IN_COUNTY \\
& \multicolumn{3}{c}{ and DIS1 } \\
\hline \multicolumn{2}{c}{ Panel A: Impact on 1940 $\ln ($ Median Home Value) (n=2921) } \\
\hline HOLC Rate & 0.003 & 0.035 & 0.085 & 0.072 \\
& $(0.002)$ & $(0.011)^{* * *}$ & $(0.026)^{* * *}$ & $(0.033)^{* *}$ \\
First stage F statistic & - & 22.13 & 11.06 & 13.12 \\
Overidentification p-value & - & 0.013 & 0.560 & - \\
\hline
\end{tabular}

Panel B: Impact on 1940 Homeownership Rate $(n=2932)$

\begin{tabular}{lcccc}
\hline HOLC Rate & 0.009 & 0.134 & 1.488 & 1.346 \\
& $(0.040)$ & $(0.189)$ & $(0.491)^{* * *}$ & $(0.658)^{* *}$ \\
First stage F statistic & - & 22.16 & 11.18 & 13.39 \\
Overidentification p-value & - & 0.000 & 0.740 & - \\
\hline
\end{tabular}

Panel C: Impact on 1935-1940 New Homes Built $(\mathrm{n}=2932)$

\begin{tabular}{lcccc}
\hline HOLC Rate & -0.013 & -0.009 & -0.011 & -0.032 \\
& $(0.004)^{* * *}$ & $(0.018)$ & $(0.034)$ & $(0.042)$
\end{tabular}

$\begin{array}{lllll}\text { First stage F statistic } & - & 22.16 & 11.18 & 13.39\end{array}$

Overidentification p-value $\quad-\quad-\quad 0.732 \quad 0.436 \quad-$

Notes: Heteroskedasticity-robust standard errors in parentheses. $* * *$ statistically significant at $1 \%$ level; ** 5\% level; * $10 \%$ level. All regressions include the demographic, economic structure, distress, political, and housing controls as well as the changes in the demographic and economic structure variables between 1930 and 1940. 
Table 5 - Robustness Checks

\begin{tabular}{|c|c|c|c|c|}
\hline & & $\begin{array}{c}\ln (\text { Median } \\
\text { Home } \\
\text { Value }) \\
\end{array}$ & $\begin{array}{c}\text { Home } \\
\text { Ownership } \\
\text { Rate }\end{array}$ & $\begin{array}{l}\ln (\mathrm{New} \\
\text { Building) }\end{array}$ \\
\hline \multirow[t]{3}{*}{$\begin{array}{l}\text { Panel A: Additional } \\
\text { Controls }\end{array}$} & Add New Deal & $\begin{array}{c}0.081 \\
(0.027)^{* * *}\end{array}$ & $\begin{array}{c}1.341 \\
(0.502)^{* * *}\end{array}$ & $\begin{array}{l}-0.031 \\
(0.036)\end{array}$ \\
\hline & Add State Fixed Effects & $\begin{array}{c}0.123 \\
(0.043)^{* * *}\end{array}$ & $\begin{array}{c}2.183 \\
(0.794) * * *\end{array}$ & $\begin{array}{l}0.007 \\
(0.047)\end{array}$ \\
\hline & Add Change in Farm & $\begin{array}{c}0.078 \\
(0.025)^{* * *}\end{array}$ & $\begin{array}{c}1.528 \\
(0.500)^{* * *}\end{array}$ & $\begin{array}{l}-0.011 \\
(0.032)\end{array}$ \\
\hline \multirow[t]{8}{*}{$\begin{array}{l}\text { Panel B: Alternate } \\
\text { Functional Forms }\end{array}$} & 10 Mile Distance Dummies & $\begin{array}{c}0.068 \\
(0.019)^{* * *}\end{array}$ & $\begin{array}{c}1.460 \\
(0.398)^{* * *}\end{array}$ & $\begin{array}{l}0.0001 \\
(0.027)\end{array}$ \\
\hline & $\begin{array}{l}30 \text { Mile Distance Dummy plus } \\
\text { Continuous Distance up to } 30 \text { Miles }\end{array}$ & $\begin{array}{c}0.089 \\
(0.025)^{* * *}\end{array}$ & $\begin{array}{c}1.523 \\
(0.477)^{* * *}\end{array}$ & $\begin{array}{l}0.009 \\
(0.032)\end{array}$ \\
\hline & Alternate HOLC Rate & $\begin{array}{c}0.050 \\
(0.016)^{* * * *}\end{array}$ & $\begin{array}{c}0.877 \\
(0.302) * * *\end{array}$ & $\begin{array}{l}-0.006 \\
(0.020)\end{array}$ \\
\hline & Amount of HOLC Loans Per Capita & $\begin{array}{c}0.032 \\
(0.013)^{* * *}\end{array}$ & $\begin{array}{c}0.544 \\
(0.215)^{* *}\end{array}$ & $\begin{array}{l}-0.004 \\
(0.012)\end{array}$ \\
\hline & Levels instead of logs & $\begin{array}{c}121.402 \\
(37.332)^{* * *}\end{array}$ & $\begin{array}{c}1.469 \\
(0.456)^{* * *}\end{array}$ & $\begin{array}{l}15.693 \\
(78.642)\end{array}$ \\
\hline & Population Dummies & $\begin{array}{c}0.081 \\
(0.026)^{* * *}\end{array}$ & $\begin{array}{c}1.595 \\
(0.515)^{* * *}\end{array}$ & $\begin{array}{l}-0.027 \\
(0.035)\end{array}$ \\
\hline & Population Density Dummies & $\begin{array}{c}0.066 \\
(0.022)^{* * *}\end{array}$ & $\begin{array}{c}1.495 \\
(0.463)^{* * *}\end{array}$ & $\begin{array}{c}0.004 \\
(0.031)\end{array}$ \\
\hline & Percent Urban Dummies & $\begin{array}{c}0.090 \\
(0.027)^{* * *}\end{array}$ & $\begin{array}{c}1.510 \\
(0.505)^{* * *}\end{array}$ & $\begin{array}{l}-0.011 \\
(0.034)\end{array}$ \\
\hline \multirow[t]{2}{*}{ Panel C: Weighting } & Weighted by $\ln$ (Population) & $\begin{array}{c}0.085 \\
(0.027)^{* * *}\end{array}$ & $\begin{array}{c}1.527 \\
(0.502) * * *\end{array}$ & $\begin{array}{l}-0.009 \\
(0.034)\end{array}$ \\
\hline & $\begin{array}{l}\text { Weighted by } \ln \text { (Nonfarm Housing } \\
\text { Units) }\end{array}$ & $\begin{array}{c}0.085 \\
(0.028)^{* * *}\end{array}$ & $\begin{array}{c}1.600 \\
(0.528)^{* * *}\end{array}$ & $\begin{array}{l}-0.008 \\
(0.035)\end{array}$ \\
\hline \multirow[t]{2}{*}{$\begin{array}{l}\text { Panel D: Alternate } \\
\text { Samples }\end{array}$} & Drop if Office In County & $\begin{array}{c}0.085 \\
(0.027)^{* * *}\end{array}$ & $\begin{array}{c}1.628 \\
(0.510)^{* * *}\end{array}$ & $\begin{array}{l}-0.005 \\
(0.035)\end{array}$ \\
\hline & Drop if Office within 15 Miles & $\begin{array}{c}0.071 \\
(0.035)^{* *}\end{array}$ & $\begin{array}{c}1.574 \\
(0.750)^{* *}\end{array}$ & $\begin{array}{l}-0.031 \\
(0.047)\end{array}$ \\
\hline \multirow[t]{4}{*}{$\begin{array}{l}\text { Panel E: Artificial } \\
\text { Offices }\end{array}$} & $\begin{array}{l}\text { Artificial Offices 1: All } 3 \text { office } \\
\text { variables as instruments }\end{array}$ & $\begin{array}{c}0.037 \\
(0.011)^{* * *}\end{array}$ & $\begin{array}{l}0.185 \\
(0.191)\end{array}$ & $\begin{array}{l}-0.001 \\
(0.018)\end{array}$ \\
\hline & $\begin{array}{l}\text { Artificial Offices 1: Only DIS1 and } \\
D I S 2 \text { as instruments }\end{array}$ & $\begin{array}{c}0.068 \\
(0.020)^{* * *}\end{array}$ & $\begin{array}{c}1.059 \\
(0.413)^{* * *}\end{array}$ & $\begin{array}{l}-0.014 \\
(0.031)\end{array}$ \\
\hline & $\begin{array}{l}\text { Artificial Offices 2: All } 3 \text { office } \\
\text { variables as instruments }\end{array}$ & $\begin{array}{c}0.022 \\
(0.010)^{* *}\end{array}$ & $\begin{array}{c}0.390 \\
(0.201)^{*}\end{array}$ & $\begin{array}{l}-0.015 \\
(0.016)\end{array}$ \\
\hline & $\begin{array}{l}\text { Artificial Offices 2: Only DIS1 and } \\
D I S 2 \text { as instruments }\end{array}$ & $\begin{array}{c}0.050 \\
(0.015)^{* * *}\end{array}$ & $\begin{array}{c}1.017 \\
(0.354)^{* * *}\end{array}$ & $\begin{array}{l}-0.019 \\
(0.024)\end{array}$ \\
\hline
\end{tabular}

See notes for Table 4. 
Figure 1 - Kernel Density Plots of Percentage Change in New Building by Distance from HOLC Office Category

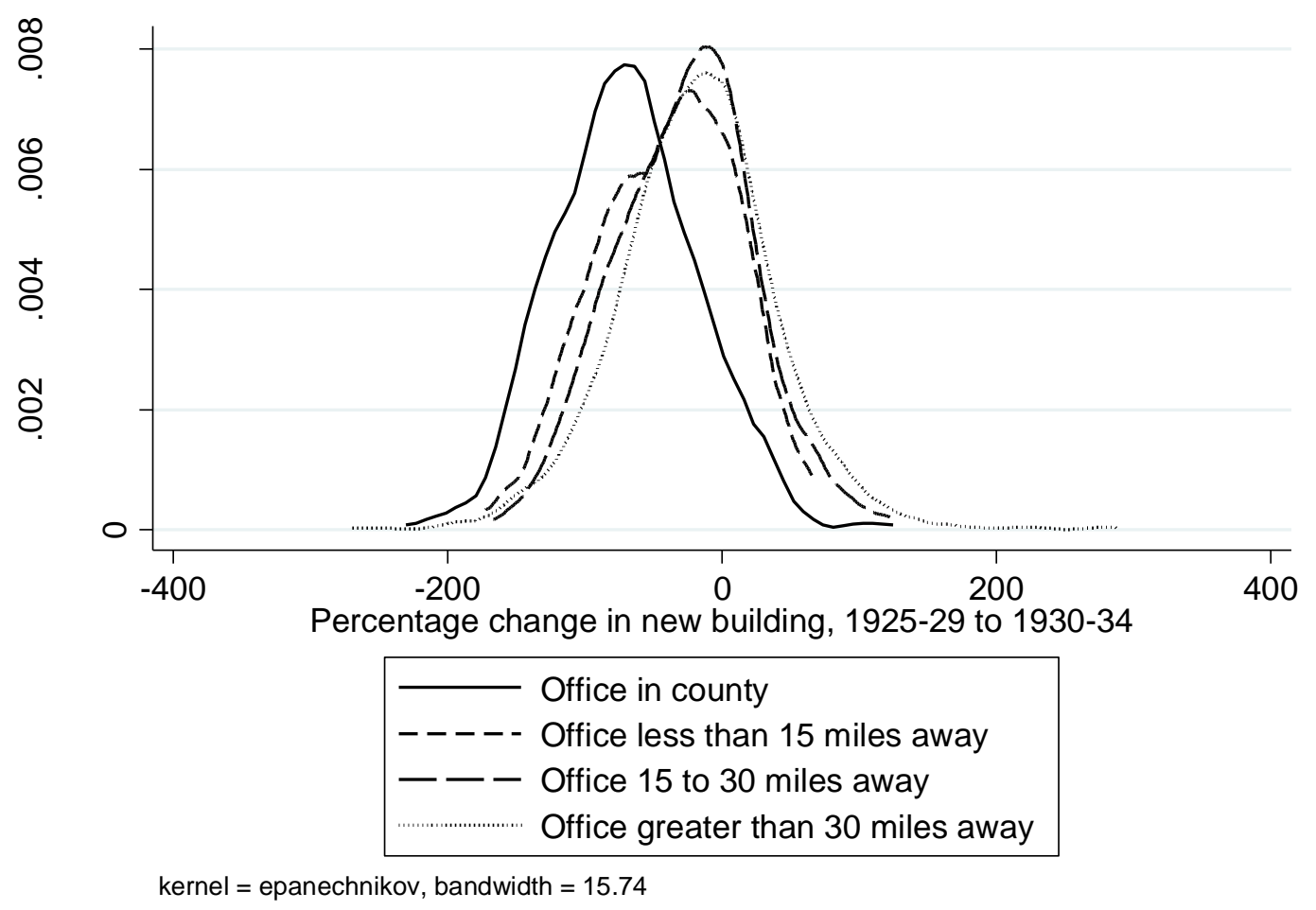

Figure 2 - Kernel Density Plots of Percentage Change in New Building by Distance from HOLC Office Category: Artificial Offices 1 


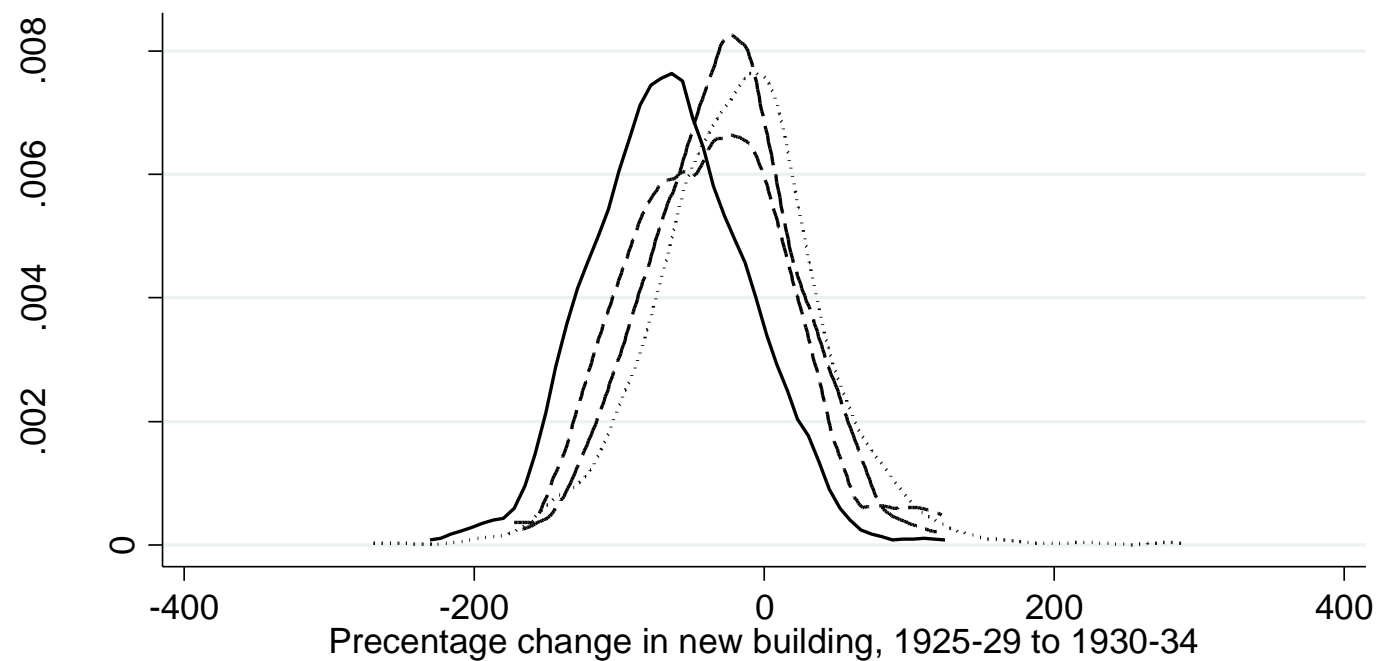

- Artificial office in county

- - - - - Artificial office less than 15 miles away

- - Artificial office 15 to 30 miles away

............. Artificial office greater than 30 miles away

kernel $=$ epanechnikov, bandwidth $=15.91$

Figure 3 - Kernel Density Plots of Percentage Change in New Building by Distance from HOLC Office Category: Artificial Offices 2 

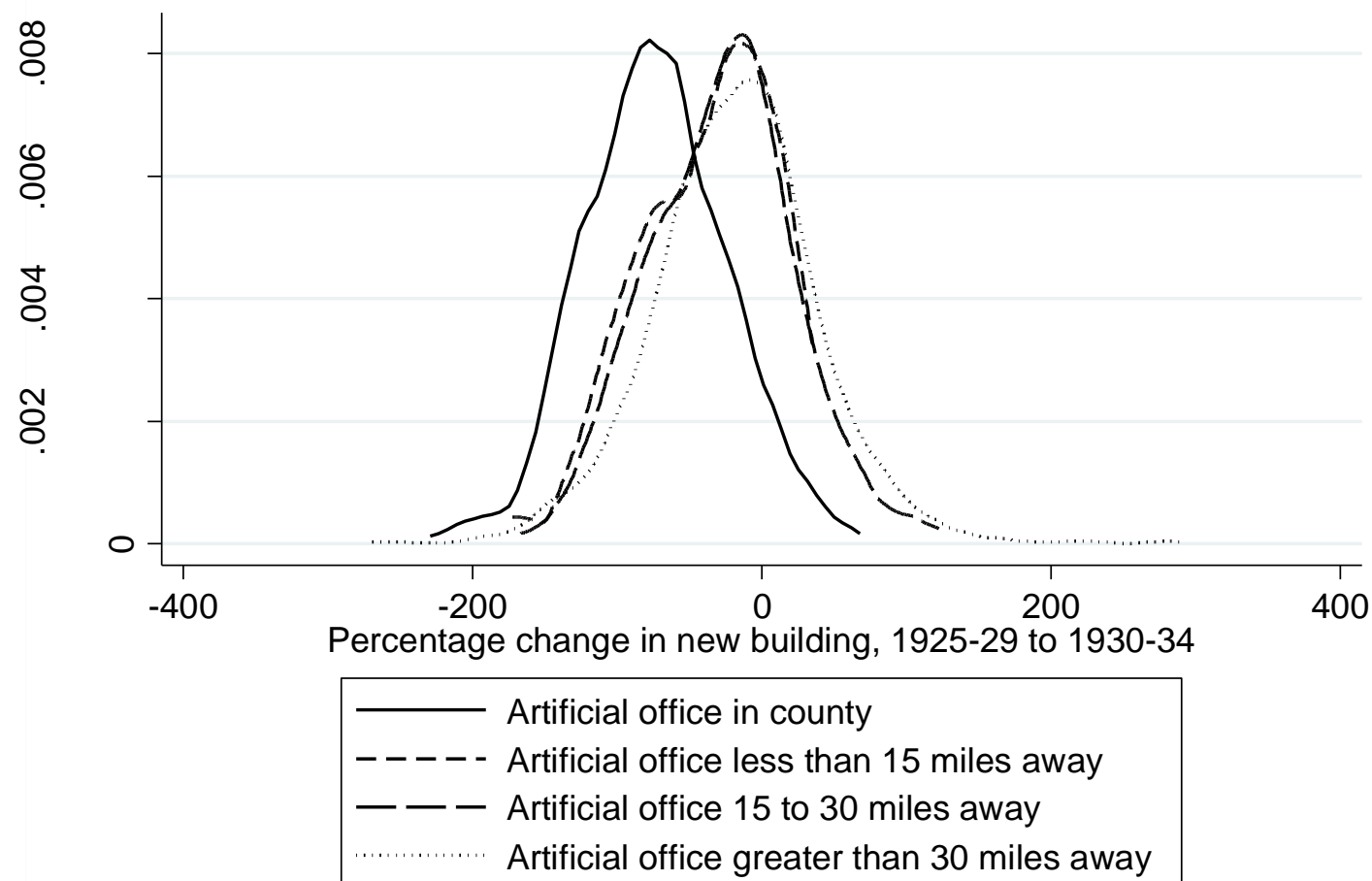

kernel $=$ epanechnikov, bandwidth $=14.85$ 